\title{
Peljhan, Matej (ur.) \\ FOTOTERAPIJA \\ Od konceptov do praks \\ Kamnik, CIRIUS, 2015
}

Zbornik Fototerapija - od konceptov do praks (2015) je pomembna zapolnitev vrzeli v slovenski literaturi na področju strokovne utemeljitve in prikaza uporabe različnih umetniških medijev kot načina vstopanja $\mathrm{v}$ odnose, $\mathrm{v} \gg$ globoko subjektivno vpletenost «. V zborniku je v ospredje postavljena fotografija. Gre za medij, ki ga danes lahko uporabljajo vsi. Tudi brez besed in brez gibanja. Če želimo, je lahko njena sporočilnost brezmejna.

Zbornik v treh sklopih (strokovni članki, prispevki iz prakse in izkušnje uporabnikov) združuje razmišljanja več avtorjev, to so: Matej Peljhan, Anita Zelić, Breda Kroflič, Robi Kroflič, Dušan Rutar, Silvo Vidergar, Jure Kravanja, Darja Štirn, Tadej Bernik, Mojca Cvirn, Nino Rakovič, Andreja Ogorevc, Jakob Škantelj, Gal Jakič in Nevenka Papič.

Eno od novejših področij pomoči z umetnostjo, lahko bi dejali tudi vzgoje prek umetnosti (Kroflič), formiranja $\mathrm{z}$ umetnostjo, izobraževanja z umetnostjo, je fototerapija. V Sloveniji je bil ustanovljen Zavod za fotografsko terapijo, kjer ob spremljanju svetovnega dogajanja uspešno razvijajo tudi svojo prakso. Zbornik je nastal v projektu s Centrom za izobraževanje, rehabilitacijo in usposabljanje (CIRIUS) Kamnik, kjer osebam s posebnimi potrebami za spodbujanje njihovega razvoja ponujajo tudi fototerapijo.

Obstaja več delitev in opredelitev fototerapije. »Fototerapija« je po Judy Weiser, kanadski psihoterapevtki, terapevtska metoda, pri kateri uporabljajo fotografijo za spodbujanje komunikacije, spominov, asociacij, čustev. Poleg tega uporabljajo tudi »terapevtsko fotografijo«, pri kateri je fotografija medij za samorazkrivanje, in »socialno angažiranje fotografske dejavnosti«, s katerim želijo rušiti stereotipe. Najbolj pogosto izraz fototerapija zajema vse tri tehnike oziroma pristope.

Začetki fototerapije v Sloveniji segajo v leto 2010, med prvimi avtorji so Anita Zelić, Matej Peljhan in Jure Kravanja. Učinkovita je za otroke, odrasle in starejše, tako da je lahko dobesedno del oziroma metoda vseživljenjskega učenja, ki omogoča samoraziskovanje, ozaveščanje misli in čustev, sodelovanje in vključevanje, ohranjanje vitalnosti pri starejših, doživetje lepega, saj gre za uporabo fotografije kot umetnostnega izraznega sredstva. Uporabljajo jo kot del rehabilitacije, za stimulacijo v psihoterapiji, ustvarjalno dejavnost za krepitev mentalnega zdravja, kot obliko izobraževanja in usposabljanja. 
Ključno izhodišče je, kot zapiše Breda Kroflič, da so ljudje ustvarjalni. Umetnostna dejavnost je splošna človekova dejavnost, ki ni omejena le na posamezne skupine izrazito nadarjenih. Umetnost je pomembna pri raziskovanju čustev, odnosov, duhovnih razsežnosti, idej in iz tega izhaja tudi umetnostna terapija (sistematično se je začela razvijati šele $\mathrm{v}$ drugi polovici 20. stoletja). Najbolj znane so dramska terapija, gibalno-plesna terapija, glasbena terapija, likovna terapija. V sodobnosti pa se razvijajo še novejše z uporabo fotografije in filma.

Peljhan (psiholog, fotograf) in Vidergar (elektroinženir in pedagog) pišeta o fotografiranju kot ustvarjalni dejavnosti, za katero potrebujemo malo fizične moči in spretnosti, z njo pa lahko ustvarimo nekaj novega in neponovljivega. To, da potrebujemo malo fizičnih spretnosti, velja v kontekstu zdravega človeka, ki niti ne opazi svoje hoje, sklanjanja, dviga aparata k očem, stabiliziranja fotoaparata in podobno. Za ljudi s posebnimi potrebami pa je nujno prilagoditi možnosti in opremo, tako da jo denimo lahko upravljajo z usti. Fizični hendikep je treba premostiti z različnimi tehničnimi prilagoditvami. Nato se lahko posvetijo razvijanju vizualnega jezika, s katerim posameznik izraža čustva, misli. Jure Kravanja (pedagog, sociolog, fotograf) opisuje fotografijo kot enega »najbolj demokratičnih medijev sodobnega časa«, ker vizualni jezik ne pozna meja, ki jih postavljajo jezikovne ovire (govor). Zelo primerna je tudi za pedagoške delavnice, različna izobraževanja lahko trajajo nekaj ur ali pa celo leto, lahko so individualna ali skupinska. CIRIUS Kamnik izvaja programe oziroma fototerapevtske delavnice od leta 2012. Namen izobraževalnih delavnic je različen. Za nekatere, ki so imeli zaradi poškodb možganov okrnjene kognitivne funkcije (percepcija, spomin, govor), so razvili posebne fotografske vaje, ki so spodbujale oziroma aktivirale prizadete funkcije, ali pa so $\mathrm{z}$ vajami razvili kompenzatorne strategije.

Publikacija je za izobraževalno področje dragocena iz več razlogov: odkrivamo fototerapijo kot novo področje, ki ga lahko vpeljemo v različne oblike izobraževalnega dela (modul fototerapija je bil vključen v program dodatnega usposabljanja mlajših odraslih - tranzicijski model), spoznavamo inovativne pristope pri razvoju metod poučevanja, seznanjamo se s posebnimi ciljnimi skupinami in njihovimi načini učenja. Postavlja pa tudi veliko izzivov in vprašanj, kako lahko z različnimi novimi tehnologijami sledimo človekovim potrebam. Ustrezna uporaba sodobne tehnologije omogoča human pristop in spodbuja razvoj zmožnosti pri ljudeh, ki teh zmožnosti z običajnimi metodami ne bi mogli razviti. Poleg umetniškega izražanja in komuniciranja je tudi vir socialnega povezovanja, vstopanja v odnose s svetom oziroma navezovanja odnosa s širšim svetom, saj se udeleženci vključujejo v fotografska društva, prirejajo razstave in podobno. Pomembno sporočilo pa je tudi v potrditvi trenda povečevanja zanimanja za različne umetniške jezike in vrste vednosti, ki jih ne moremo zajeti z znanstveno vednostjo.

V zadnjih 30 letih se spoznanja o emocijah, tehnologija, virtualni svetovi, duhovno, kritična refleksija povezujejo v konglomerate, kjer se uporabljajo različna komunikacijska sredstva. Hkrati pa se razvija tudi spoznanje, da posamezniki svet vidimo različno, na iste informacije se odzovemo različno, kar poudarja A. Zelić v svojem prispevku: »Vsak 
izmed nas vidi in doživi isto fotografijo drugače.«In nas tako spodbudi tudi k razmisleku o različnosti oziroma drugačnosti. Za 21. stoletje postaja bolj kot koncept drugačnosti oziroma posebnih potreb pomemben koncept humane raznolikosti in nevroraznolikosti ( $h u$ man diversity, neurodiversity), ${ }^{1}$ ki kaže na potrebo, naj izobraževalne metode in programi dosegajo raznolike ljudi na raznolike načine. Novi pogledi na »normalno« in »tipično« so bolj učinkoviti za oblikovanje vključujočih praks, saj ne uporabljajo neprimerne dihotomne delitve ljudi na tiste, ki imajo posebne potrebe, in one, ki so »normalni.$^{2}$ Fototerapija je del novih paradigem; je metoda, ki je vsem na voljo, je prilagodljiva, sledi potrebam in zmožnostim posameznika in je vir za inovativne strategije učenja in poučevanja.

V CIRIUS Kamnik so hkrati izdali še dve publikaciji, ki so dostopne na njihovih spletnih straneh (http://www.cirius-kamnik.si/knjigeclanki). Tako Hendikep, delo in družba (ur. Rutar, Dušan; Kralj, Ror in Praznik, Irena) kot Tranzicijski model (ur. Kožar, Dijana) pomembno dopolnjujeta že obstoječe (še vedno pogosto predvsem psihomedicinske) opredelitve hendikepa v slovenskem prostoru. Gre za strokovno utemeljen in pedagoško bogato zastavljen prikaz tranzicijskega programa, s katerim populaciji, ki po dolgoletnem bivanju zapušča CIRIUS Kamnik, omogočajo prehod v bolj samostojno in neodvisno življenje. Gre za temeljno pravico in potrebo vsakega posameznika ne glede na hendikep. Ker so trenutne možnosti za različne inkluzivne oblike zaposlitev oseb s posebnimi potrebami v Sloveniji zelo skope, so pobude, ki vzniknejo znotraj posameznih institucij, še toliko več vredne in pomembnejše. Še dodatno kličejo državo k odgovornosti za ureditev področja zunaj začasnih, projektno vodenih rešitev.

Katja Jeznik

1 Armstrong, T. (2012). Neurodiversity in the Classroom: Strength-Based Strategies to Help Students with Special Needs Succeed in Schools and Life. Alexandria: ASCD.

2 Smith, T., Polloway, E., Patton, J. Dowdy, C. A. (2012). Teaching Students with Special Needs in Inclusive Settings. Boston: Pearson. 